\title{
Pelatihan Pendampingan Pembuatan Peta Tematik Menggunakan GPS dan Aplikasi CAD
}

\section{(Training Assistance in Making Thematic Maps Using GPS and CAD Applications)}

\author{
Andrew Stefano ${ }^{1 *}$, Sri Endayani ${ }^{2}$ \\ 1 Program Studi Teknologi Geomatika, Politeknik Pertanian Negeri Samarinda, Jl. Samratulangi \\ Kampus Politani Samarinda 75131. \\ 2 Program Studi Kehutanan, Fakultas Pertanian, Universitas 17 Agustus 1945 Samarinda, Jl. Ir. H. Juanda No.80 \\ Samarinda 75123. \\ *Penulis Korespondensi: andrew.stefano@politanisamarinda.ac.id \\ Diterima September 2019/Disetujui Juli 2020
}

\begin{abstract}
ABSTRAK
Salah satu masalah dalam pengembangan profesionalisme sumber daya manusia selama ini adalah terkait dengan persoalan peta tematik batas wilayah 10 Kecamatan Kota Samarinda. Tujuan kegiatan ini adalah untuk memberikan pelatihan tentang penggunaan GPS dan pengolahan data menggunakan software autodesk map. Pelatihan ini diikuti oleh para staf kelurahan dan kecamatan Kota Samarinda, sebanyak 50 orang. Metode yang digunakan adalah 1) Pemberian pengetahuan teoritis dan praktis tentang pengambilan serta pengolahan data; 2) Penugasan pembuatan batas perwilayah; 3) Presentasi hasil di lapangan; dan 4) Output (peta batas). Hasil kegiatan adalah: p ertama, semua peserta kegiatan pelatihan ini sangat antusias, bersemangat, dan mempunyai motivasi yang tinggi mengikuti pelaksanaan kegiatan pelatihan pembuatan batas. Kedua, peserta kegiatan yang berhasil membuat peta batas sejumlah 25 orang atau $50 \%$ dari 50 peserta. Ketiga, kualitas peta termasuk kategori cukup baik. Mereka menemukan perbedaan bentuk peta batas antara versi Bappeda Kota Samarinda dan pengambilan data lapang. Pada Kelurahan Bugis, Kecamatan Samarinda berdasarkan data lapang dari staf Kelurahan Bugis bentuk peta batas lahan hampir menyerupai peta batas lahan Bappeda Kota Samarinda selisih 2,5 ha, dikarenakan Bappeda Kota Samarinda tidak memasukkan Stadion GOR Segiri sebagai area Kelurahan Bugis yang seharusnya dimasukkan sebagai peta batas. Hasil peta dari para staf kelurahan Kecamatan Samarinda Kota dirapatkan kembali oleh pihak camat dan lurah untuk ditetapkan sebagai peta Kecamatan Kota Samarinda dan di printout A0 dipajang dimasing-masing kantor kelurahan yang berada di Kecamatan Samarinda Kota.
\end{abstract}

Kata kunci: pelatihan, pembuatan batas batas, staf

\begin{abstract}
One of the problems in the development of human resource professionalism so far is related to land issues (boundaries). The purpose of this activity is to provide training on the use of GPS and processing data using Autodesk map software. The training was attended by the village and sub-district staff of Samarinda City, as many as 50 people. The method used is 1) giving theoretical and practical knowledge about data collection and processing 2) assignment of making land boundaries per area, 3) presentation of results in the field and 4) output (boundary map). The results of this activity were: First, all participants of this training activity were very enthusiastic, enthusiastic, and had high motivation to take part in the implementation of the second boundary land making training activity, the participants who succeeded in making a land boundary map of 25 people or $50 \%$ of 50 participants. Third, the quality of the maps is quite good. They found differences in boundary map shape between version Samarinda City Bappeda and field data collection. Based on field data from the Bugis Kelurahan staff, the shape of the land boundary map in the Bugis sub-district in Samarinda almost resembles the land boundary map of Samarinda City of 2.5 ha, because Samarinda City Bappeda does not include the Segiri GOR Stadium as an area of Bugis sub-district that should be included as a map of the border. The map results from Samarinda Kota sub-district staff were recombined by sub-district and sub-district lurah to be determined as a map of sub-district Kota Samarinda and displayed in the A0 printout in each of the kelurahan offices located in sub-district Samarinda Kota.
\end{abstract}

Keywords: land limit making, staff, training 


\section{PENDAHULUAN}

Indonesia merupakan negara yang berada pada kawasan yang sangat cepat berkembang karena secara geografis berada pada jalur perdagangan dunia (Pasific Ocean Rim dan Indian Ocean Rim) (Brenner et al. 2012; Bradter et al. 2019; Ampadu et al. 2020). Meskipun begitu, Indonesia juga tidak diuntungkan secara geografis karena terletak pada kawasan pertemuan tiga lempeng tektonik yang mengakibatkan wilayahnya rawan akan bencana (Brown et al. 2013; Chen et al. 2019; Cobb \& Oliver 1997). Oleh karena itu, Indonesia harus memiliki suatu perencanaan yang strategis dalam penataan wilayahnya sebagai alat bantu dalam perumusan kebijakan dan pengambilan keputusan (Doyle et al. 1998; Gad \& Kusky 2006; García-álvarez et al. 2019). Salah satunya dengan cara menampilkan informasi-informasi yang terdapat di daerahnya ke dalam peta sebab dengan peta kita dapat memperoleh informasi yang kita butuhkan dalam konteks keruangan dengan lebih efisien dan efektif (Hobbs \& Chan 1990; Kabiri et al. 2018; Hossain \& Meng 2020). Sebagai peta dasar pelatihan digunakan peta yang dibuat oleh Bappeda Kota Samarinda 2011-2031.

Peta dasar maupun data informasi spasial lainnya memiliki peran yang sangat strategis dalam menjaga keutuhan suatu negara, perencanan serta pengawasan pembangunan, dan penataan ruang. Akan tetapi, hingga kini kesadaran pemerintah dan masyarakat akan manfaat dan pentingnya peta masih sangat rendah (Malczewski 2004, Koshkarev et al. 2008; Lu et al. 2011). Padahal, Indonesia saat ini merupakan satu-satunya Negara yang memiliki Undang-Undang tentang Informasi Geospasial Nasional (UU IG-N), yaitu Undang-Undang Nomor 4 Tahun 2011. Indonesia juga memiliki UndangUndang Nomor 26 Tahun 2007 tentang penataan ruang, namun sayangnya kedua Undang-Undang tersebut masih belum diimplementasikan dengan baik oleh pemerintah maupun masyarakat. Di Indonesia maupun banyak negara berkembang lain, perencanaan tata ruang sudah merupakan alat pemerintahan baku yang dibuat secara berkala pada tingkat nasional, propinsi, kabupaten dan bahkan kelurahan, akan tetapi alat ini seringkali kehilangan makna dan fungsinya dikarenakan oleh pendekatan dan proses pembuatannya yang tidak tepat (Mason et al. 2013; Mitchell et al. 2018; Mitchell et al. 2018).
Hal ini banyak disebabkan oleh kurangnya kapasitas maupun keterampilan sumber daya manusianya, kurang kondusifnya kebijakan yang ada, serta kurangnya integrasi antar sektoral. Akibatnya, dapat terjadi tumpang tindih alokasi yang bisa mengakibatkan konflik antar pemangku kepentingan dan program-program pembangunan yang tidak efisien (Puhr et al. 2014; Ottosen et al. 2020; Petrognani \& Robert 2020). Seperti kebanyakan daerah lainnya di Indonesia, Kecamatan Kota Samarinda Provinsi Kalimantan Timur, masih menyajikan informasi geospasialnya dengan belum memenuhi kaidah kartografi yang berlaku. Padahal berdasarkan perda Nomor 17 Tahun 2002 tentang Rencana Tata Ruang Wilayah (RT/RW) akan di kelurahan menjadi pusat perkotaan melalui program Zonasi yang akan mengarahkan daerah tersebut dan sekitarnya bertransformasi menjadi kota yang besar. Artinya akan terjadi banyak perubahan pada Kecamatan tersebut demi menunjang program pemerintah tersebut (Rafaelli et al. 2001; Ryu et al. 2014; Smith 2016; Sardi \& Pulungan 2019).

Penyajian informasi geospasial yang baik merupakan hal yang sangat penting dilakukan oleh kedua pemerintahan tersebut guna tercapainya pembangunan yang berkelanjutan (Wang 2005; Steiniger \& Hunter 2013; Thomas et al. 2015; Suyadi et al. 2017). Dalam konteks ini pemerintah kelurahan memerlukan adanya suatu sistem basis data yang memadai. Hal ini meliputi pengetahuan lokal maupun formal mengenai penghidupan masyarakat, fungsi biofisik dan sumber daya manusia (Zaslavsky 2003; Yu et al. 2015; Dall'Agnol et al. 20200). Data-data seperti kesesuaian batas, iklim, pemukiman, populasi, pasar, jalan, penggunaan batas serta perubahannya, dan penunjukan kawasan merupakan data penunjang yang sangat diperlukan dalam proses perencanaan yang memerlukan sistem yang padu. Dengan suatu sistem informasi geospasial yang terpadu antar setiap kelurahan maka perencanaan strategis terkait tata ruang dan wilayah dapat diintegrasikan satu sama lainnya (Zeilhofer \& Topanotti 2008). Maka peningkatan kapasitas dan keterampilan sumber daya manusia dalam hal ini perangkat kelurahan dan teknologi pendukungnya merupakan hal yang mutlak dilakukan demi tercapainya pembangunan yang berkelanjutan (Zaslavsky 2003).

Peta yang dihasilkan oleh perangkat kelurahan masih banyak yang belum memenuhi kaidah kartografi dan juga banyak yang belum 
menampilkan informasi geospasial secara optimal pada petanya (Yu et al. 2015). Masalah lainnya juga dapat terlihat pada informasi geospasial yang ditampilkan pada peta yang dihasilkan oleh kelurahan masing-masing belum mencakup keseluruhan informasi yang terdapat pada kelurahan yang bersangkutan. Selain itu sistem informasi geospasial kelurahan terpadu harus dapat dilakukan oleh para perangkat kelurahan secara berkelanjutan (Dall'Agnol et al. 20200). Oleh karena itu, diperlukan peningkatan kapasitas dan keterampilan sumber daya untuk menyajikan informasi geospasial dengan baik dalam bentuk peta (Wang 2005). Tujuan dari kegiatan untuk memberikan keterampilan kepada perangkat kelurahan dalam membuat peta sesuai dengan kaidah kartografi dan dapat menyusun serta menampilkan informasi geospasial daerahnya di dalam peta yang berguna membantu perencanaan dan pengembangan kelurahan masing-masing di masa depan (Thomas et al. 2015). Sehingga, dapat tercipta suatu sistem informasi geospasial kelurahan terpadu yang dijalankan oleh pemerintah kelurahan secara mandiri dan berkelanjutan.

Kegiatan ini diharapkan dapat membantu perangkat kelurahan dalam membuat peta sesuai dengan kaidah kartografi dan dapat menyusun serta menampilkan informasi geospasial dengan baik (Suyadi et al. 2017). Selain itu diharapkan terciptanya suatu sistem informasi geospasial kelurahan yang terpadu dari kemandirian pemerintah kelurahan tersebut (Steiniger \& Hunter 2013). Sehingga, kebutuhan pemerintah maupun masyarakat tersedianya informasi geospasial yang baik dapat terpenuhi. Secara fisik, hasil dari kegiatan ini diharapkan menghasilkan (Smith 2016): a) Modul pelatihan, berisi tutorial tentang membuat peta sesuai dengan kaidah kartografi dan penyusunan serta penyajian informasi geospasial pada peta; b) $C D$ tutorial, berisi tentang software pemetaan digital Map Source dan Autodesk Map, modul pelatihan yang berbentuk softcopy, dan juga video tutorial tentang pembuatan peta sesuai dengan kaidah kartografi. CD tutorial ini juga berisi cara penyusunan dan penyajian informasi geospasial yang baik; c) Peta batas administrasi Kota Samarinda, berisi tentang peta yang dihasilkan saat pelatihan oleh perangkat kelurahan peserta pelatihan mengenai informasi kelurahannya; dan d) Papan informasi, menampilkan peta yang dihasilkan saat pelatihan yang berisi informasi geospasial kelurahan agar dapat diakses oleh masyarakat dengan mudah.
Kegiatan pelatihan membuat peta berdasarkan kaidah kartografi dan penyusunan informasi geospasial untuk perangkat kelurahan diharapkan dapat memberikan manfaat sebagai berikut (Sardi \& Pulungan 2019): a) Menghasilkan perangkat kelurahan yang memiliki keterampilan membuat peta berdasarkan kaidah kartografi dan penyusunan informasi geospasial yang baik; b) Kelurahan yang mengikuti pelatihan dapat menyajikan informasi geospasial kelurahannya dengan lebih lengkap dan efisien; c) Mempermudah masyarakat atau orang yang memerlukan informasi geospasial kelurahan tersebut secara lebih lengkap; d) Meningkatakan antusiasme dan kepercayaan masyarakat terhadap kemajuan pembangunan kelurahannya; e) Terciptanya suatu sistem informasi geospasial yang baik dan terintegrasi antara kelurahan yang satu dengan kelurahan lainnya; f) Membantu analisis informasi spasial kelurahan guna penentuan rancangan arah pembangunan kelurahan; g) Membantu pengambil kebijakan pada perangkat pemerintahan yang lebih tinggi dalam mengambil keputusan terkait berbagai pemecahan masalah kelurahan; dan h) Sebagai wadah aktualisasi diri mahasiswa dalam bekerjasama dan kemandirian demi kepentingan masyarakat.

Kecamatan Samarinda Kota memiliki 59 kelurahan dan 10 kecamatan. Pada Kecamatan ini sedang terjadi proses transformasi dari kelurahan ke perkotaan yang mengakibatkan terjadinya perubahan pada kondisi dan perilaku masyarakatnya (Ryu et al. 2014). Misalnya kita dapat melihatnya pada perubahan pola penggunaan tanahnya yang dahulu batasnya banyak digunakan sebagai batas pertanian dan perkebunan sekarang banyak berubah menjadi jalan dan bangunan-bangunan (Rafaelli et al. 2001). Sistem kepemilikan tanah juga banyak terjadi perubahan akibat banyaknya terjadi migrasi penduduk dari luar Kota Samarinda dan sekitarnya ke daerah ini (Puhr et al. 2014). Hal ini kita dapat kita lihat pada banyaknya tanah warisan penduduk asli yang dijual kepada para pendatang atau pihak-pihak lainnya yang tentunya akan mendorong pembangunan aktivitas fisik di daerah tersebut (Petrognani \& Robert 2020). Perbedaan hasil diambil dilapangan dengan peta batas dibuat oleh Bappeda Kota Samarinda dirapatkan oleh Camat Samarinda Kota dan Lurah (Gambar 1).

Akan tetapi, upaya yang seharusnya dilakukan dalam mengantisipasi peningkatan pembangunan yang terjadi tidak sejalan dengan usaha pemerintah kelurahannya dalam menye- 
diakan informasi geospasial yang mengikuti perkembangan wilayahnya (Ottosen et al. 2020). Pada beberapa kelurahan yang terdapat di Kecamatan Kota Samarinda masih menampilkan informasi geospasial kelurahannya dengan belum memenuhi kaidah kartografi yang berlaku sehingga masyarakat akan sulit menangkap dengan baik informasi geospasial yang disajikan (Mitchell et al. 2018). Sarana penyajian informasi geospasialnya juga masih terbatas dan kurang mencukupi demi tersajinya informasi spasial yang baik (Mason et al. 2013).

\section{METODE PELAKSANAAN KEGIATAN}

Menggambar peta batas Kota Samarinda dimaksudkan agar staf Pemerintahan Kota Samarinda dapat menggambarkan tata letak unsur-unsur yang terdapat pada batas di atas media kertas agar secara transparan dapat diketahui oleh masyarakat luas tentang kondisi dan situasi aktual batas Kota Samarinda, lebih lanjut peta tersebut dapat dipergunakan sebagai alat bantu dalam perencanaan rehabilitasi dan pengembangan pemanfaatan batas Kota Samarinda. Unsur batas yang digambarkan oleh staf Pemerintah Kota Samarinda pada peta batas didasarkan pada kondisi yang ada di lapangan. Untuk menghindari konflik status batas yang dapat diakibatkan oleh hasil peta batas hasil pelatihan ini, maka proses penggambaran peta batas, termasuk saat pengukuran batas di lapangan, kelompok Staf Pemerintahan Kota Samarinda yang melaksanakan pemetaan batas perlu didampingi oleh perangkat desa/ kelurahan.

\section{Tempat dan waktu pelatihan.}

Pelatihan dilaksanakan selama \pm 12 (Dua Belas) bulan yang dimulai dari bulan Januari sampai dengan Desember yang bertempat di Kota Samarinda. Pelatihan melibatkan Seluruh SKPD Pemerintahan Kota Samarinda.

\section{Peralatan Dan Bahan.}

Peralatan dan bahan untuk menggambar peta lahan disesuaikan dengan tahap pelaksanaannya. Alat bahan pengukuran adalah kertas HVS ukuran A4 untuk membuat tabel pengukuran di lapangan, kertas glossy A0 dan dibingkai untuk mencetak hasil final pengukuran, clip board (papan landasan untuk mencatat pengukuran di lapangan) untuk tabel pengukuran, pensil HB,

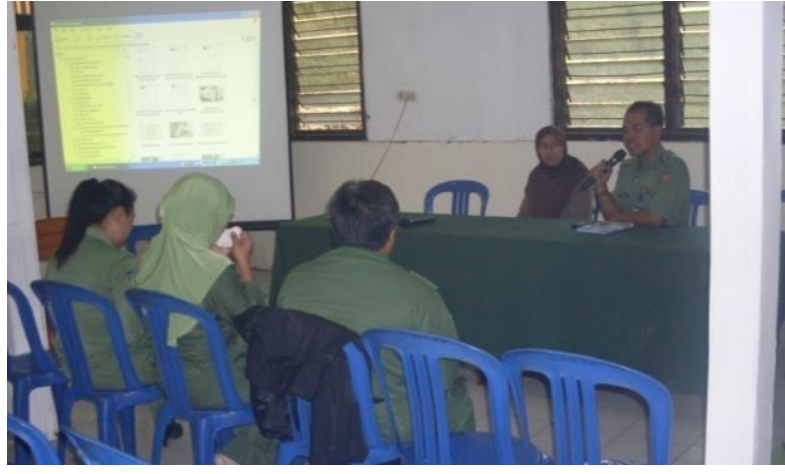

Gambar 1 Rapat dengan camat dan lurah.

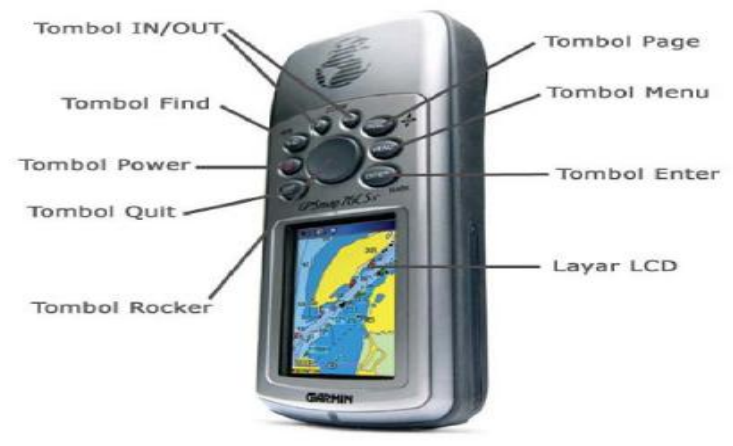

Gambar 2 GPS 76 CSX.

rautan pensil, karet penghapus, GPS Navigasi Garmin 76 CSX (Gambar 2).

Kegiatan pengabdian kepada masyarakat dilaksanakan di 10 Kecamatan Kota Samarinda. Metode pelaksanaan kegiatan berupa:

- Metode ceramah khususnya terkait dengan pemahaman terhadap penggunaan GPS; proses penyusunan pencatatan data lapangan; dan proses pengolahan data lapangan;

- Metode pemberian tugas pembuatan peta presisi sesuai dengan kaidah kartografi. Pelaksanaan kegiatan melibatkan kelompok sasaran para staf kelurahan dan kecamatan Kota Samarinda. (Gambar 3).

\section{HASIL DAN PEMBAHASAN}

Kota Samarinda dibentuk dan didirikan pada tanggal 21 Januari 1960, berdasarkan UU Darurat No. 3 Tahun 1953, Lembaran Negara No. 97 Tahun 1953 tentang Pembentukan daerahdaerah Tingkat II Kabupaten/kotamadya di Kalimantan Timur. Semula Kodya Dati II Samarinda terbagi dalam 3 kecamatan, yaitu Kecamatan Samarinda Ulu, Samarinda Ilir dan Samarinda Seberang. Kemudian dengan SK Gubernur Kepala Daerah Tingkat I Provinsi Kalimantan Timur No. 18/SK/TH-Pem/1969 dan 
SK No. 55/TH-Pem/SK/1969, terhitung sejak tanggal 1 Maret 1969, wilayah administratif Kodya Dati II Samarinda ditambah dengan 4 kecamatan, yaitu Kecamatan Palaran, SangaSanga, Muara Jawa dan Samboja (luas sekitar $2.727 \mathrm{~km}^{2}$ ).

Saat ini pembagian kecamatan di Samarinda tidak termasuk Sanga-Sanga, Muara Jawa dan Samboja, ketiganya masuk dalam Kabupaten Kutai Kartanegara. Setelah PP No. 38 Tahun 1996 terbit, wilayah administrasi Kodya Dati II Samarinda mengalami pemekaran, semula terdiri dari 4 kecamatan menjadi 6 kecamatan, yaitu Kecamatan Sungai Kunjang, Samarinda Ulu, Samarinda Utara, Samarinda Ilir, Samarinda Seberang, dan Palaran.

Pemekaran kecamatan kembali dilakukan seiring dengan pertumbuhan penduduk yang cukup pesat dan pelayanan masyarakat yang semakin meningkat. Kecamatan-kecamatan di Samarinda yang semula berjumlah 6, kini dimekarkan menjadi 10 kecamatan, 4 kecamatan hasil pemekaran tersebut antara lain: Kecamatan Samarinda Kota, Loa Janan Ilir, Sambutan, dan Sungai Pinang. Peresmian kecamatan tersebut dilaksanakan pada tanggal 28 Desember 2010. Jadi, secara administratif Kota Samarinda dibagi menjadi 10 kecamatan dan 53 kelurahan. Ada pun pada tahun 2014 kelurahan di Samarinda bertambah enam sehingga menjadi 59 kelurahan.

Indikator keberhasilan kegiatan pelatihan dari sisi proses ini, juga tampak dari hasil evaluasi yang didasarkan pada taraf respons peserta, mengenai kebermanfaatan kegiatan pelatihan yang diikuti, dengan dengan empat kategori yakni, sangatbermanfaat (81\%), bermanfaat (19), kurang bermanfaat (0), dan tidak bermanfaat $(0)$, sebagaimana dapat dilihat pada Tabel 1.

Produk peta batas batas yang dihasilkan dapat disampaikan, yakni bahwa dari sisi presisi dan akurasi pengolahan data yang berhasil diselesaikan oleh para staf kelurahan dan kecamatan, dapat dikategorikan kurang, sebab hanya terkumpul 25 orang atau $50 \%$ dari 50 peserta yang ada. Sementara itu terkait dengan sisi kualitasnya, peta batas batas yang dihasilkan tersebut termasuk dalam kategori cukup baik. Hasil koordinat data lapang yang diambil dengan menggunakan GPS 60 CSX (Tabel 2).

Indikator dari kualitas yang cukup baik tersebut, diantaranya tampak dari keterbatasan terkait dengan pengambilan data lapang, pengolahan data dengan menggunakan Microsoft excel dan ditransfer datanya ke Autodesk Map

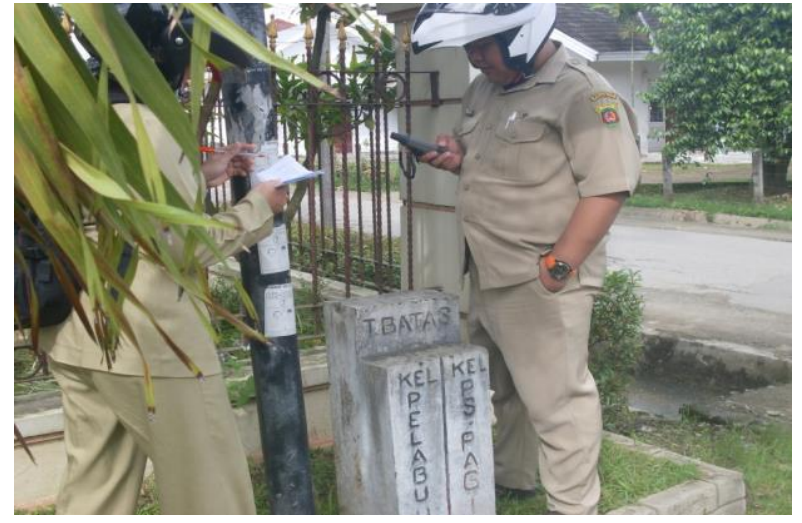

Gambar 3 Pengambilan data lapangan.

Tabel 1 Respons peserta mengenai kebermanfaatan kegiatan pelatihan

\begin{tabular}{clc}
\hline $\begin{array}{c}\text { Interval } \\
(\%)\end{array}$ & \multicolumn{1}{c}{ Kategori } & $\begin{array}{c}\text { Persentase } \\
(\%)\end{array}$ \\
\hline $86-100$ & Sangat bermanfaat & 81 \\
$66-85$ & Bermanfaat & 19 \\
$36-65$ & Kurang bermanfaat & 0 \\
$0-35$ & Tidak bermanfaat & 0 \\
\hline
\end{tabular}

untuk melihat hasil pengukuran. Crosscheck data dapat juga menggunakan citra Quickbird. Terjadi perbedaan bentuk wilayah batas di 5 kelurahan Samarinda Kota. Batas yang paling terlihat perbedaannya adalah Kelurahan Sungai Pinang Luas antara versi Bappeda dengan pengambilan data lapang oleh staff kelurahan (Gambar 4).

Batas yang paling mirip dengan dengan peta batas Bappeda Kota adalah Kelurahan Bugis, meskipun masih dapat selisih seluas 2,5 ha karena Stadion Segiri tidak dimaksukkan ke dalam wilayah Kelurahan Bugis oleh pihak Bappeda (Gambar 5). Berdasarkan data hasil berupa produk peta batas batas dari kegiatan pelatihan, baik dari sisi kuantitas maupun kualitas tersebut, dapat disampaikan bahwa semakin menguatkan betapa pentingnya pengambilan data lapang sesuai dengan kaidah kartografi, terutama dalam konteks kelurahan dan kecamatan.

\section{SIMPULAN}

Dari sisi proses pelatihan pendampingan pembuatan peta tematik termasuk dalam kategori baik, dengan indikator diantaranya kehadiran peserta yang mencapai $100 \%$, semua tampak sangat antusias, bersemangat, dan mempunyai motivasi yang sangat tinggi mengikuti pelatihan. Fenomena tersebut, disebabkan oleh tingkat kebutuhan atau kepentingan 
Tabel 2 Formulir pengukuran GPS

\begin{tabular}{|c|c|c|c|c|c|}
\hline & \multicolumn{4}{|c|}{ Laboratorium geodesi program studi geoinformatika } & \multirow{2}{*}{$\begin{array}{l}\text { Halaman } 1 \\
\text { Mendung }\end{array}$} \\
\hline Proyek & & \multirow{4}{*}{\multicolumn{2}{|c|}{$\begin{array}{l}\text { Tapal batas } \\
\text { Kelurahan Pasar Pagi } \\
\text { Garmin } 60 \text { CSX }\end{array}$}} & Cuaca & \\
\hline Lokasi & & & & Surveyor & Syamsul Anwar, SE \\
\hline Jenis alc & & & & Recorder & Siti Amanah, SE \\
\hline \multicolumn{2}{|c|}{ No. Seri alat } & & & Tanggal & 10 Juli 2013 \\
\hline Point & Easting & Northing & Elevation & Estimated accuracy & Description \\
\hline $\mathrm{p} 1$ & 516704 & 9945189 & 13 & 3,9 & Perbatasan pelabuhan \\
\hline $\mathrm{p} 2$ & 516666 & 9945199 & 18 & 3,2 & Perbatasan Basuki Rahmat \\
\hline p3 & 516660 & 9945215 & 17 & 3,9 & Titik tengah Rumah Sakit Derajat \\
\hline $\mathrm{p} 4$ & 516643 & 9945197 & 20 & 3,0 & Simpangan derajat lampu merah \\
\hline p5 & 516657 & 9945185 & 15 & 3,9 & Simpang derajat agnesti \\
\hline p6 & 516620 & 9945029 & 19 & 3,9 & Jalan Telen Tengah br PU \\
\hline p7 & 516622 & 9945031 & 20 & 3,7 & Belakang rumah Dinas PU \\
\hline p8 & 516634 & 9945021 & 14 & 3,7 & Tengah jalan Telen \\
\hline p9 & 516611 & 9944976 & 19 & 4,0 & Gang 4 Abdul Hasan \\
\hline $\mathrm{p} 10$ & 516598 & 9944943 & 02 & 6,1 & Gang 5 Abdul Hasan \\
\hline p11 & 516563 & 9944856 & 15 & 5,2 & Gang 8 Abdul Hasan \\
\hline $\mathrm{p} 12$ & 516544 & 9944865 & 19 & 4,2 & Gang 8 dinding belakang Senyiur \\
\hline $\mathrm{p} 13$ & 516525 & 9944800 & 22 & 4,2 & Gang H Masri samping Senyiur \\
\hline $\mathrm{p} 14$ & 516468 & 9944797 & 16 & 3,2 & Jalan Abdul Hasan \\
\hline $\mathrm{p} 15$ & 516459 & 9944770 & 16 & 3,5 & Tapal batas di Pancang \\
\hline p16 & 516456 & 9944765 & 19 & 3,5 & Tengah simpul Panegoro \\
\hline p17 & 516490 & 9945239 & 19 & 4,0 & Gang 3 Jalan Basuki Rahmat \\
\hline $\mathrm{p} 18$ & 516496 & 9945202 & 23 & 4,9 & Gang 3 Dalam \\
\hline $\mathrm{p} 19$ & 516379 & 9945163 & 29 & 8,0 & Belakang Rumah Sakit Bakti Nugraha \\
\hline $\mathrm{p} 20$ & 516389 & 9945155 & 20 & 3,0 & Dinding Kuburan Muslim \\
\hline $\mathrm{p} 21$ & 516332 & 9945111 & 19 & 5,0 & Sudut Tembok Kuburan \\
\hline $\mathrm{p} 22$ & 516336 & 9945032 & 25 & 5,0 & Dinding Tembok Kuburan \\
\hline $\mathrm{p} 23$ & 516335 & 9945004 & 19 & 3,2 & Sudut Tembok Kuburan \\
\hline p24 & 516341 & 9944981 & 21 & 4,0 & Perbatasan RT 24 Asrama \\
\hline p25 & 516341 & 9944909 & 18 & 4,5 & Perbatasan RT 15 Asrama \\
\hline p26 & 516339 & 9944893 & 18 & 3,5 & Perbatasan RT 15 Asrama \\
\hline $\mathrm{p} 27$ & 516338 & 9944866 & 18 & 4,5 & Sudut Perbatasan Bugis \\
\hline $\mathrm{p} 28$ & 516297 & 9944876 & 18 & 4,1 & Sudut Perbatasan Bugis \\
\hline p29 & 516256 & 9944865 & 20 & 4,0 & Belakang Sekolah SD \\
\hline p30 & 516222 & 9944850 & 19 & 6,6 & Samping Sekolah SD \\
\hline p31 & 516163 & 9944669 & 18 & 3,5 & Perbatasan Jalan Jambrut \\
\hline p32 & 516152 & 9944673 & 15 & 4,0 & Perbatasan Jalan Virus \\
\hline p33 & 516146 & 9944664 & 19 & 3,4 & Perbatasan Jalan Virus \\
\hline
\end{tabular}

para staf kelurahan dan kecamatan terkait adanya kompetensi pengambilan data lapangan dan pengolahan, sebagai salah satu bagian dalam peningkatan profesionalisme mereka. Kemudian dari sisi hasil produk, berupa peta batas yang dihasilkan baik dari sisi kuantitas dan kualitas, termasuk dalam kategori baik. Dari sisi kuantitas atau peta batas yang berhasil diselesaikan dan diserahkan kepada tim pelaksana kegiatan pengabdian kepada masyarakat, hanya berjumlah 25 buah atau $50 \%$ dari 50 peserta. Dari sisi kualitasnya dapat disampaikan bahwa, peta batas yang dihasilkan dalam kategori cukup baik. Ada beberapa kekurangan yang masih perlu mendapatkan perhatian terkait peta batas yang dihasilkan, misalnya adalah terkait dengan cara pengambilan data lapangan, pengolahan data dengan program Microsoft excel, transfer koordinat ke Autodesk Map dan koreksi citra Quikbird. Staf yang dikirim pada saat pelatihan bukanlah bidang pemerintahan, khususnya bidang pemetaan. Jadi penguasaan pada materi pelatihan sangat minim. 

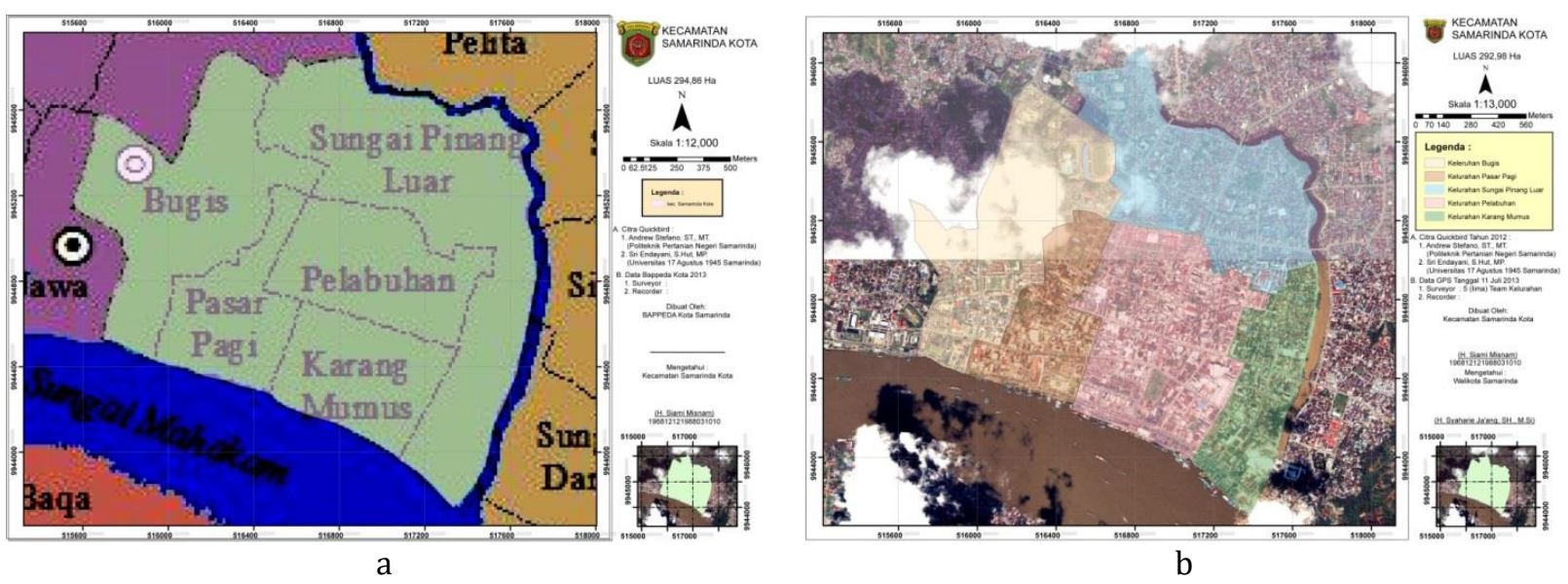

Gambar 4 Peta Kecamatan Samarinda Kota, a) Versi Bappeda Kota Samarinda dan b). Versi pengambilan data lapangan oleh staff Kecamatan Samarinda Kota.
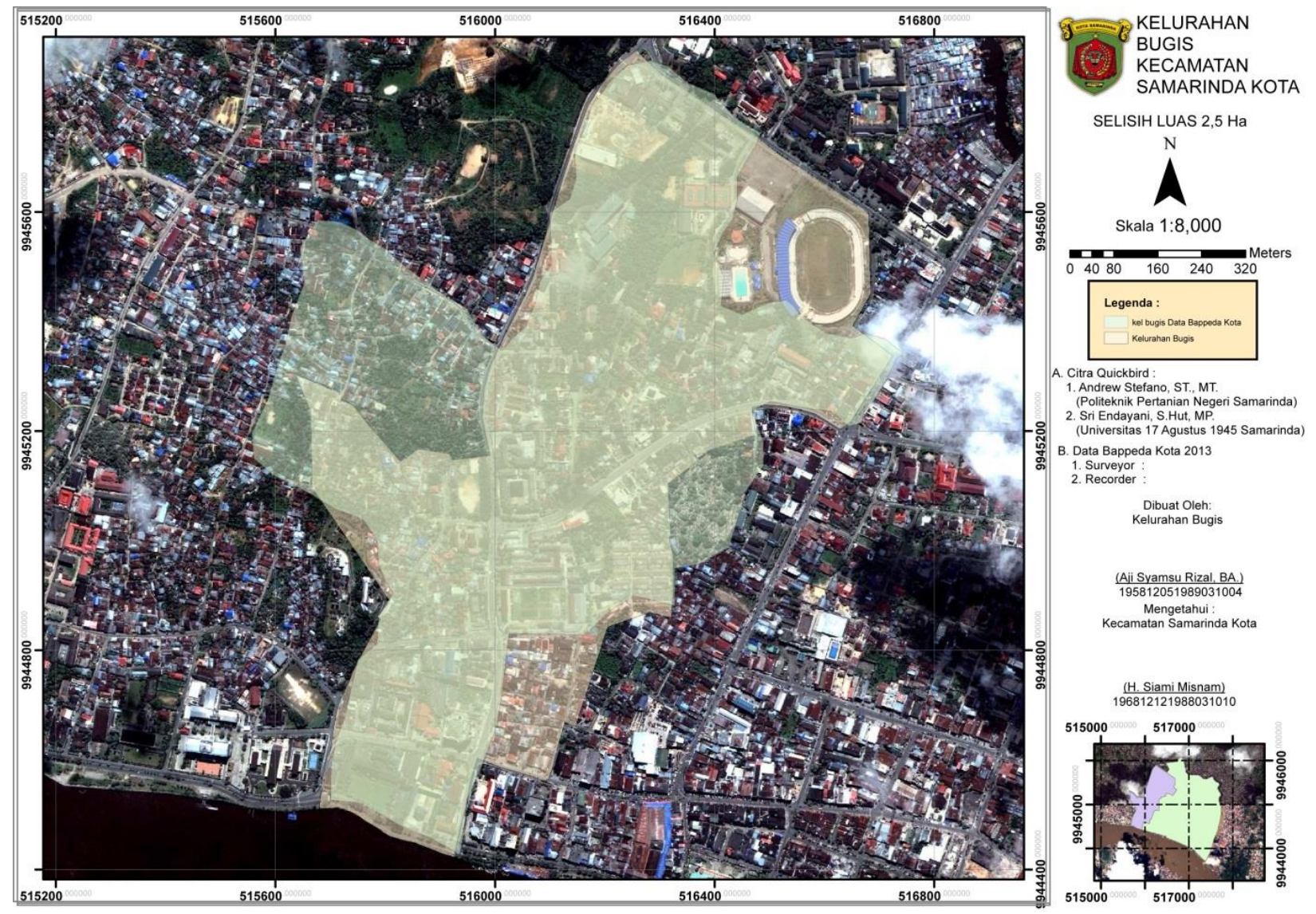

Gambar 5 Peta Kecamatan Samarinda Kota, a) Versi Bappeda Kota Samarinda dan b) Versi pengambilan data lapangan oleh staff Kecamatan Samarinda Kota.

\section{DAFTAR PUSTAKA}

Ampadu EG, Gebreslasie M, Ponce AM. 2020. Mapping Natural Forest Cover Using Satellite Imagery of Nkandla Forest Mapping natural forest cover using satellite imagery of Nkandla forest reserve, KwaZulu-Natal, South Africa. Remote Sensing Applications: Society and Environment. 1-18. https://doi.org/10.1016/ j.rsase.2020.100302
Bradter U, O'Connell J, Kunin WE, Boffey CWH, Ellis RJ, Benton TG. 2019. Classifying GrassDominated Habitats from Remotely Sensed Data: The Influence of Spectral Resolution, Acquisition Time and the Vegetation Classification System on Accuracy and Thematic Resolution. Science of the Total Environment. 711: 1-5. https://doi.org/ 10.1016/j.scitotenv.2019.134584 
Brenner JC, Christman Z, Rogan J. 2012. Segmentation of Landsat Thematic Mapper Imagery Improves Buffelgrass ( Pennisetum Ciliare ) Pasture Mapping in the Sonoran Desert of Mexico. Applied Geography. 34: 569575. $\quad$ https://doi.org/10.1016/j.apgeog. 2012.02.008

Brown M, Sharples S, Harding J. 2013. Introducing PEGI : A Usability Process for the Practical Evaluation of Geographic Information. Journal of Human Computer Studies. 71(6): 668-678. https://doi.org/ 10.1016/j.ijhcs.2013.01.004

Chen S, Wang W, Liang H. 2019. Evaluating the Effectiveness of Fusing Remote Sensing Images with Significantly Different Spatial Resolutions for Thematic Map Production. Physics and Chemistry of the Earth Parts $A / B / C$. 110: 71-80. https://doi.org/10.1016/j.pce. 2018.09.002

Cobb DA, Oliver A. 1997. Online GIS Service. The Journal of Academic Librarianship. November (1997): 484-497. https://doi.org/ 10.1016/S0099-1333(97)90173-7

Dall'Agnol RW, Michelon GK, Bazzi CL, Magalhães PSG, De Souza EG, Betzek NM, Sobjak R. 2020. Web Applications for Spatial Analyses and Thematic Map Generation. Computers and Electronics in Agriculture. 172: 1-13. https://doi.org/10.1016/j.compag.2020.105 374

Doyle S, Dodge M, Smith A. 1998. The Potential Of Web-Based Mapping And Virtual Reality Technologies For Modelling Urban Environments. Computers, Environment and Urban Systems. 22 (2): 137-55. https://doi.org/10.1016/S0198-9715(98) 00014-3

Gad S, Kusky T. 2006. Lithological Mapping in the Eastern Desert of Egypt , the Barramiya Area, Using Landsat Thematic Mapper (TM). Journal of African Earth Sciences. 44(2): 196-202. https://doi.org/10.1016/j.jafrearsci.2005.10. 014

García-álvarez D, Lloyd CD, Delden HV , Teresa M, Olmedo C. 2019. Thematic resolution influence in spatial analysis. An application to Land Use Cover Change (LUCC) modelling calibration. Computers, Environment and
Urban Systems. 78: 1-13. https://doi.org/ 10.1016/j.compenvurbsys.2019.101375

Hobbs F, Chan C. 1990. AutoCAD as a Cartographic Training Tool: A Case Study. Computer-Aided Design. 22 (3). 151-157. https://doi.org/10.1016/0010-4485(90) 90073-L

Hossain MK, Meng Q. 2020. A Thematic Mapping Method to Assess and Analyze Potential Urban Hazards and Risks Caused by Flooding. Computers, Environment and Urban Systems. 79: 1-19. https://doi.org/10.1016/ j.compenvurbsys.2019.101417

Kabiri K, Rezai H, Moradi M. 2018. Mapping of the Corals around Hendorabi Island (Persian Gulf), Using WorldView-2 Standard Imagery Coupled with Fi Eld Observations. Marine Pollution Bulletin. 129 (1). 266-74. https:// doi.org/10.1016/j.marpolbul.2018.02.045

Koshkarev AV, Antipov AN, Batuyev AR, Yermoshin VV, Karakin VP. 2008. Geo-Portals as Part of Spatial Data Infrastructures: Russian Academy-Supported Resources and Geoservices. Geography and Natural Resources. 29(1): 18-27. https://doi.org/ 10.1016/j.gnr.2008.04.005

Lu D, Li G, Moran E, Batistella M, Freitas CC. 2011. Mapping Impervious Surfaces with the Integrated Use of Landsat Thematic Mapper and Radar Data: A Case Study in an UrbanRural Landscape in the Brazilian Amazon. ISPRS Journal of Photogrammetry and Remote Sensing. 66(6): 798-808. https://doi.org/ 10.1016/j.isprsjprs.2011.08.004

Malczewski J. 2004. GIS-Based Land-Use Suitability Analysis: A Critical. Progress in Planning. 62(1): 3-65. https://doi.org/ 10.1016/j.progress.2003.09.002

Mason PJ. 2013. Remote Sensing / GIS. In: Reference Module in Earth Systems and Environmental Sciences. Elsevier Inc. https://doi.org/10.1016/B978-0-12-4095489.02955-9

Mitchell PJ, Downie AL, Diesing M. 2018. How Good Is My Map? A Tool for Semi-Automated Thematic Mapping and Spatially Explicit Confidence Assessment. Environmental Modelling and Software. 108: 111-122. 
https://doi.org/10.1016/j.envsoft.2018.07.0 14

Mitchell PJ, Downie AL, Diesing M. 2018. Environmental Modelling \& Software How Good Is My Map? A Tool for Semi-Automated Thematic Mapping and Spatially Explicit Con Fi Dence Assessment. Environmental Modelling and Software. 108: 111-22. https://doi.org/10.1016/j.envsoft.2018.07.0 14

Ottosen TB, Petch G, Hanson M, Skjoth CA. 2020. International Journal of Applied Earth Observation and Geoinformation. 84: 1-12.

Petrognani S, Robert E. 2020. Reports Dating without Dates: Stylistic and Thematic Chronologies in the Paleolithic Painted Caves of Les Bernoux and Saint-Front (Dordogne, France ). Journal of Archaeological Science: Reports. 31: (1-9). https://doi.org/ 10.1016/j.jasrep.2020.102260

Puhr K, Schultz S, Pikelj K, Petricioli D, Petricioli TB. 2014. The Performance, Application and Integration of Various Seabed Classi Fi Cation Systems Suitable for Mapping Posidonia Oceanica ( L .) Delile Meadows. Science of the Total Environment. 470-471: 364-378. https://doi.org/10.1016/j.scitotenv.2013.09. 103

Rafaelli SG, Montgomery DR, Greenberg HM. 2001. A Comparison of Thematic Mapping of Erosional Intensity to GIS-Driven Process Models in an Andean Drainage Basin. 244(12): 33-42. https://doi.org/10.1016/S00221694(00)00419-4

Ryu JH, Jong-kuk Choi JK, Lee YK. 2014. Potential of Remote Sensing in Management of Tidal Flats: A Case Study of Thematic Mapping in the Korean Tidal Flats. Ocean and Coastal Management. 102(B): 458-470. https:// doi.org/10.1016/j.ocecoaman.2014.03.003

Sardi J, Pulungan AB. 2019. Pelatihan Reparasi Dan Perawatan Alat Listrik Rumah Tangga Untuk Pemuda Pesisir. 3(1): 3-6. https:// doi.org/10.30595/jppm.v3i1.2396

Smith DA. 2016. Online Interactive Thematic Mapping: Applications and Techniques for
Socio-Economic Research. Computers, Environment and Urban Systems. 57: 106-117. https://doi.org/10.1016/j.compenvurbsys.20 16.01.002

Steiniger S, Hunter AJS. 2013. The 2012 Free and Open Source GIS Software Map-A Guide to Facilitate Research, Development, and Adoption. Computers, Environment and Urban Systems. 39: 136-50. https://doi.org/ 10.1016/j.compenvurbsys.2012.10.003

Suyadi A, Nugroho B. 2017. Pelatihan Memanfaatkan Lahan Sempit untuk Budidaya Sayuran Organik. Jurnal Pengabdian dan Pemberdayaan masyarakat. 1(2): 95-102. https://doi.org/10.30595/jppm.v1i2.1633

Thomas RF, Kingsford RK, Lu Y, Cox SJ, Sims NC, Hunter SJ. 2015. "Mapping Inundation in the Heterogeneous Floodplain Wetlands of the Macquarie Marshes, Using Landsat Thematic Mapper. Journal of Hydrology. 524: 194-213. https://doi.org/10.1016/j.jhydrol.2015.02.02 9

Wang X. 2005. Integrating GIS, Simulation Models , and Visualization in Traffic Impact Analysis. Computers, Environment and Urban Systems. 29(4): 471-96. https://doi.org/ 10.1016/j.compenvurbsys.2004.01.002

Yu L, Shi Y, Gong P. 2015. Land Cover Mapping and Data Availability in Critical Terrestrial Ecoregions: A Global Perspective with Landsat Thematic Mapper and Enhanced Thematic Mapper plus Data. Biological Conservation. 190: 34-42. https://doi.org/ 10.1016/j.biocon.2015.05.009

Zaslavsky I. 2003. Chapter 11-Online Cartography with XML. Maps and the Internet. 2003: 171-196. https://doi.org/10.1016/ B978-008044201-3/50013-X

Zeilhofer P, Topanotti VP. 2008. GIS and Ordination Techniques for Evaluation of Environmental Impacts in Informal Settlements: A Case Study from Cuiaba Central Brazil. Applied Geography. 28(1): 1$15 . \quad$ https://doi.org/10.1016/j.apgeog. 2007.07.009 